\title{
Peningkatan Peran Dewan Kemakmuran Masjid sebagai Fungsi Edukasi dalam Pelaksanaan Kurban di Tengah Pandemi Covid-19
}

\section{(The Increasing Role of 'Dewan Kemakmuran Masjid' as An Educational Function in the Implementation of Sacrifices during Covid-19 Pandemic Situation)}

\author{
Ridi Arif ${ }^{*}$, Ardilasunu Wicaksono ${ }^{1}$, Andriyanto ${ }^{2}$, Dede Sholeh ${ }^{3}$ \\ 1 Departemen Ilmu Penyakit Hewan dan Kesehatan Masyarakat Veteriner, Fakultas Kedokterah Hewan, \\ Institut Pertanian Bogor, Kampus IPB Darmaga 16680. \\ 2 Departemen Anatomi, Fisiologi, dan Farmakologi, Fakultas Kedokterah Hewan, Institut Pertanian Bogor, \\ Kampus IPB Darmaga 16680. \\ 3 Dewan Kemakmuran Masjid An-Nashir, Perumahan Taman Darmaga Permai 2, Cihideung Udik, Ciampea, Bogor 16620. \\ *Penulis Korespondensi: ridiarif88@apps.ipb.ac.id \\ Diterima Agustus 2020/Disetujui Maret 2021
}

\begin{abstract}
ABSTRAK
Situasi pelaksanaan ibadah kurban pada tahun $1441 \mathrm{H}$ atau $2020 \mathrm{M}$ berbeda dengan pelaksanaan di tahuntahun sebelumnya karena berlangsung di tengah pandemi Covid-19. Kejadian pandemi terjadi sejak awal tahun 2020 dan belum berakhir hingga dilaksanakannya ibadah kurban pada tanggal 31 Juli 2020. Pemerintah telah mengeluarkan kebijakan terkait pelaksanaan kurban di tengah pandemi Covid-19. Meskipun demikian, masih muncul permasalahan di tengah masyarakat, yaitu keraguan akan keamanan pelaksanaan kurban di tengah masa pandemi. Kegiatan pengabdian masyarakat ini bertujuan untuk memaksimalkan peran Dewan Kemakmuran Masjid (DKM) dalam melakukan edukasi, sosialisasi, dan mengawal kebijakan pemerintah terkait pelaksanaan kurban di tengah pandemi. Kegiatan pengabdian ini terdiri atas evaluasi kesiapan pelaksanaan kurban, penyusunan media edukasi kurban di tengah pandemi, dan contoh pelaksanaan kurban yang baik di tengah pandemi yang dilakukan oleh DKM Masjid An-Nashir, Desa Cihideung Udik, Ciampea, Bogor. Responden berjumlah 40 orang dari beragam kelompok masyarakat dan daerah di Indonesia mengikuti evaluasi secara online untuk menilai kesiapannya dalam pelaksanaan kurban. Kelompok masyarakat umum mendapatkan poin rata-rata 7,05 yang berarti kurang siap sedangkan kelompok DKM mendapatkan poin 8,25 $\pm 1,28$ yang berarti telah siap. Hal tersebut menunjukkan DKM mampu untuk mengedukasi dan membantu masyarakat dalam pelaksanaan kurban di tengah pandemi Covid-19. Selain DKM yang aktif memberikan edukasi, dalam kegiatan pengabdian ini juga dibagikan tautan yang berisi materi dan buku saku kurban digital yang dapat diunduh secara gratis sehingga dapat membantu edukasi pelaksanaan kurban yang baik dan aman di tengah pandemi.
\end{abstract}

Kata kunci: covid-19, DKM, kurban, pandemi

\begin{abstract}
The situation of sacrificial day in $1441 \mathrm{H}$ was different from the previous years because it will be held during Covid-19 pandemic situation. The pandemic started in the beginning of 2020 and were not over until the day of sacrifice on July 31,2020 . The government has issued a policy for the day of sacrifices during Covid-19 pandemic situation. Nevertheless, there were still remain problems in the community about the security aspects and the potential spread out of covid-19. This community service activity aims to maximize the role 'Dewan Kemakmuran Masjid' (DKM) in conducting education, socialization, and controlling government policies related to the implementation of sacrificial day during pandemic situation. The activity consists of evaluation of the readiness for sacrificial day implementation, preparation of sacrificial education media during the pandemic, and examples of good practices carried out by DKM An-Nashir Mosque, Cihideung Udik Village, Ciampea, Bogor. As many as 40 respondents from various groups and regions in Indonesia participated in an online evaluation to assess their readiness for sacrificial day. The average point was 7.05 that means people were still poorly prepared while DKM group gets $8.25 \pm 1.28$ which means it is ready. This shows that DKM was able to educate and serve the community in the implementation of sacrifices during Covid-19 pandemic situation. In addition, in this activity also distributed a link containing material and digital sacrificial pocket books that can be downloaded for free so as to help education on the sacrifice implementation with good and safe practices.
\end{abstract}

Keywords: covid-19, day of sacrifice, DKM, pandemic 


\section{PENDAHULUAN}

Awal pandemi Covid-19 yang disebabkan oleh SARS Corona Virus-2 pertama kali dilaporkan terjadi di Wuhan, China pada akhir Desember 2019 dan telah menyebar secara luas di seluruh dunia (Wu et al. 2020). Infeksi oleh Covid-19 dapat menyebabkan gangguan pernapasan dengan gejala ringan sampai berat dan diperlukan isolasi khusus bagi penderita untuk mencegah terjadinya penularan dan penyebaran (Yuliana 2020). Bahkan di beberapa Negara telah melakukan lock down di berbagai wilayahnya karena diyakini dapat mencegah penularan dan penyebaran virus serta dapat menekan terjadinya pandemi (Atalan 2020).

Penyebaran pandemi di Indonesia telah terdeteksi sejak awal Maret 2020 telah memberikan banyak perubahan drastis dalam tatanan kehidupan bermasyarakat. Perubahan tersebut sebagai wujud dari kepatuhan masyarakat dalam mengikuti instruksi pemerintah terkait kebijakan pengendalian Covid-19 di Indonesia. Mulai dari sektor industri sampai dengan sektor pendidikan mengalami berbagai perubahan untuk mnyesuaikan pada kebijakan yang dikeluarkan pemerintah, yaitu Pembatasan Sosial Berskala Besar (Muhyiddin \& Wardhana 2020). Sampai dengan pertengahan tahun 2020, pandemi Covid19 masih juga belum berakhir namun di sisi lain kehidupan masyarakat harus terus bergulir. Oleh karenanya, pemerintah membantu masyarakat untuk memasuki fase tatanan kehidupan baru di tengah pandemi Covid-19. Dalam memasuki tatanan baru di tengah pandemi ini, pemerintah telah memberikan panduan dalam berbagai sektor sehingga diharapkan masyarakat dapat beraktifitas normal namun juga berpartisipasi dalam mengurangi penyebaran Covid-19 (Habibi 2020). Salah satu tatanan kehidupan baru yang dilakukan masyarakat di tengah pandemi ini adalah pelaksanaan ibadah kurban $1441 \mathrm{H}$. Pelaksanaan ibadah ini sebagai wujud ketaatan umat muslim terhadap perintah agamanya dan sudah semestinya dalam pelaksanaannya di tengah pandemi ini perlu mengikuti tatanan baru. Dalam pelaksanaannya juga perlu menerapkan protokol kesehatan karena dengan menerapkannya juga berarti menjalankan ajaran yang disampaikan dalam agama (Fitriyana 2020).

Pelaksanaan ibadah kurban di Indonesia merupakan salah satu yang terbesar di dunia. Dengan jumlah penduduk muslim terbesar di dunia, maka mayarakat yang melaksanakan ibadah kurban dan melakukan kegiatan penyembelihan hewan kurban di hari raya ini menjadi sangat banyak. Ketersediaan hewan kurban untuk memenuhi kebutuhan masyarakat juga sangat mencukupi, terlebih lagi dilaporkan bahwa populasi hewan ternak di Indonesia meningkat jumlahnya dari tahun 2018-2019 (BPS 2020; Deptan 2020). Umat muslim sangat bersemangat untuk melaksanakan ibadah kurban ini sebagai bukti ketaatan dan pendekatan diri pada Tuhannya (Mulyana 2016; Saputra et al. 2019). Terlebih lagi dengan adanya fatwa MUI no 36 tentang pelaksanaan Idul Adha dan pnyembelihan kurban di tengah wabah Covid-19 yang menjelaskan terkait teknis pelaksanaannya (MUI 2020).

Pada tahun 2019, jumlah hewan kurban yang dipotong telah mencapai sekitar 1,3 juta ekor yang terdiri atas sapi, kerbau, kambing, dan domba (Departemen Pertanian 2020). Untuk mengawal pelaksanaan pemotongan hewan kurban sampai dengan penyediaan daging kurban yang aman dan sehat untuk masyarakat, pemerintah pusat dan daerah bekerja sama serta dibantu oleh pihak terkait selalu melakukan pemeriksaan dan monitoring. Pada tahun 2020 ini, kegiatan pemeriksaan dan monitoring tersebut dibatasi karena pihak terkait yang biasa membantu juga dikurangi keterlibatannya. Hal tersebut dilakukan untuk menyesuaikan dengan kebijakan pemerintah, yaitu tentang protokol kesehatan bagi masyarakat saat berada di tempat dan fasilitas umum dalam rangka pencegahan dan pengendalian Covid-19 (Kementerian Kesehatan 2020). Di sisi lain, dinas yang membidangi sektor peternakan dan kesehatan hewan terus melakukan usaha edukasi kepada masyarakat terkait dengan pelaksanaan kurban di tengah pandemi. Salah satu yang gencar dilakukan adalah melakukan seminar secara online untuk mensosialisasikan protokol pelaksanaan kurban di tengah pandemi.

Pemerintah melalui Surat Edaran No. 0008/SE/PK.320/F/06/2020 tentang Pelaksanaan Kegiatan Kurban dalam Situasi Wabah Bencana Nonalam Corona Virus Disease (Covid19) telah memberikan panduan protokol pelaksanaan kegiatan kurban di tengah pandemi. Peraturan ini telah lengkap memberikan panduan dari pemilihan hewan kurban sampai dengan pembagian daging kurban kepada masyarakat dengan menyesuaikan pada aturan protokol kesehatan agar tidak terjadi perluasan penyebaran Covid-19. Di sisi lain, masih banyak masyarakat yang belum mengetahui protokol dan tatanan baru dalam pelaksanaan kurban di 
masa pandemi. Masyarakat juga masih banyak yang menanyakan terkait dengan kemungkinan penularan Covid-19 melalui hewan kurban baik saat masih hidup maupun setelah dipotong. Oleh karena itu, kegiatan pengabdian masyarakat ini bertujuan untuk mengedukasi masyarakat terkait dengan permasalahan tersebut dengan memanfaatkan peran DKM sebagai lini terdepan dalam pelaksanaan ibadah kurban.

\section{METODE PELAKSANAAN KEGIATAN}

Pelaksanaan kegiatan ini terdiri atas evaluasi kesiapan pelaksanaan kurban, penyusunan media edukasi kurban di tengah pandemi, dan contoh pelaksanaan kurban yang baik oleh DKM Masjid An-Nashir, Desa Cihideung Udik, Ciampea, Bogor. Evaluasi kesiapan pelaksanaan kurban dilakukan secara online. Format evaluasi online ini digunakan juga sebagai self assessment/ penilaian kesiapan diri bagi responden dalam pelaksanaan ibadah kurban di tengah pandemi. Pertanyaan dalam evaluasi kesiapan ini terdiri atas pertanyaan dengan jawaban ya atau tidak dan pertanyaan dengan jawaban pendek dengan total 13 pertanyaan. Partisipan dalam evaluasi ini terdiri atas masyarakat umum baik yang akan berkurban maupun tidak, petugas pemeriksa kesehatan hewan, dan panitia kurban/pengurus Dewan Kemakmuran Masjid (DKM). Evaluasi online ini dilakukan selama 7 hari sebelum pelaksanaan Idul Kurban.

\section{Alur kegiatan pengabdian}

Kegiatan diawali dengan penyusunan perangkat evaluasi online kesiapan pelaksanaan kurban. Proses pembuatan perangkat evaluasi ini terdiri atas 4 tahapan, yaitu pembuatan pertanyaan evaluasi, pembuatan form online, pembuatan flyer digital, dan broadcast melalui aplikasi WA. Pertanyaan evaluasi dibuat ringkas yang terdiri atas pertanyaan dengan jawaban singkat dan pertanyaan dengan jawaban ya atau tidak. Pertanyaan dengan jawaban teks pendek menanyakan tentang lokasi tempat tinggal dan pertanyaan yang dapat diajukan oleh responden. Pertanyaan dengan jawaban ya atau tidak terdiri atas 10 pertanyaan yang otomatis akan memberikan nilai setelah selesai dikerjakan. Kelompok pertanyaan ini sekaligus menjadi evaluasi diri kesiapan pelaksanaan kurban. Pengkategorian nilai hasil pengerjaan, yaitu nilai 8-10 = siap; nilai $6-8=$ kurang siap; nilai < $6=$ tidak siap. Pertanyaan evaluasi kemudian dituliskan pada perangkat online google form. Untuk membuat lebih menarik, dibuat juga flyer dan kalimat broadcast melalui aplikasi Whatsapp (WA). Flyer yang disebarkan kepada masyarakat disajikan pada Gambar 1.

Selanjutnya, dilakukan pembuatan perangkat edukasi bagi masyarakat, yaitu berupa buku saku kurban digital dan tautan (link) materi seminar online kurban mengenai pelaksanaan kurban di masa pandemi. Buku saku kurban yang disiapkan merupakan modifikasi dari buku saku kurban milik panitia kurban FKH IPB tahun 2019 dan pada tahun 2020 buku tersebut dilengkapi dengan poin pelaksanaan kurban di masa pandemi Covid-19. Link materi seminar online disediakan dengan menautkan pada materi seminar milik Departemen Ilmu Penyakit Hewan dan Kesehatan Masyarakat Veteriner, Fakultas Kedokteran Hewan IPB terkait pembahasan kurban di masa pandemi. Materi edukasi ini disediakan secara resmi di situs web fkh.ipb.ac.id dan dapat diakses secara luas oleh masyarakat. Proses pengumpulan data dimulai dengan menyebarkan flyer digital dan broadcast WA ke masyarakat umum. Data yang masuk dipantau pada spreadsheet yang telah dibuat. Selain itu juga dilihat jumlah pengunjung dan yang mendownload materi edukasi yang telah disediakan di website FKH IPB. Data yang terkumpul dikelompokkan sesuai variabel pertanyaan dan kemudian disajikan dalam bentuk tabel dan grafik. Data dianalisis secara kuantitatif pada variabel status keterlibatan masyarakat terhadap nilai kesiapan pelaksanaan kurban sedangkan variabel lain dianalisis secara deskriptif.

Sebagai contoh pelaksanaan kurban yang baik dan mematuhi peraturan pemerintah, DKM Masjid An-Nashir telah mempersiapkan protokol

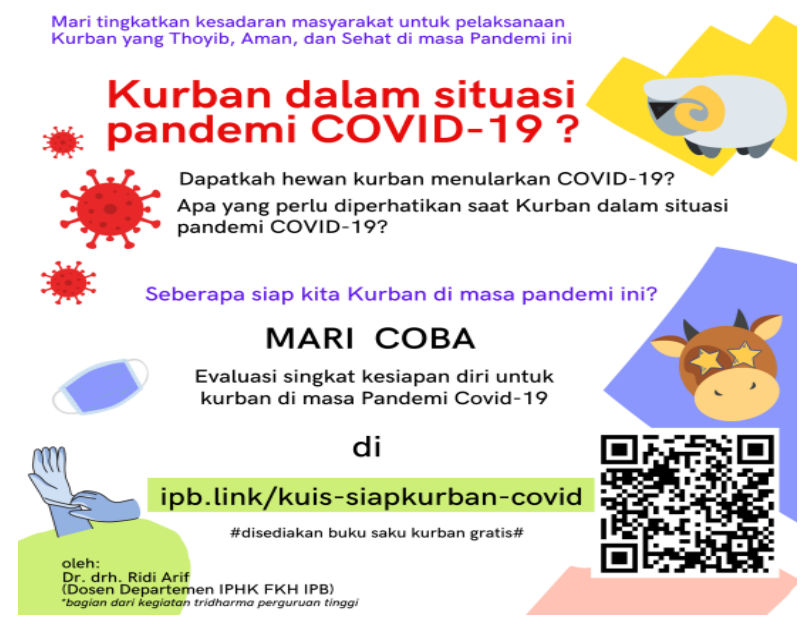

Gambar 1 Flyer digital untuk evaluasi kesiapan kurban. 
pelaksanaan kurban di masa pandemi. Persiapan ini telah dimulai sebulan sebelum dilaksanakannya Idul Kurban yang dimulai dengan pembentukan panitia, pembuatan denah alur proses pelaksanaan kurban, penyiapan peralatan, penyiapan protokol kesehatan, dan memberikan edukasi kepada masyarakat sekitar mengenai protokol pelaksanaan kurban di tengah pandemi yang dilakukan melalui pengeras suara maupun secara personal oleh anggota DKM.

\section{HASIL DAN PEMBAHASAN}

Kegiatan evaluasi kesiapan pelaksanaan kurban telah diikuti sebanyak 40 partisipan dengan latar belakang berasal dari beragam daerah yaitu Kota Bogor, Tanah Datar, Ngada, Wonosobo, Kabupaten Bogor, Subulussalam, Aceh Besar, Bekasi, Bandung, Subang, Cirebon, Makassar, Lampung Selatan, Surabaya, Lhokseumawe, Lampung Tengah, Bengkayang, Tangerang Selatan, Pemalang, Depok, dan Boyolali. Partisipan yang tersebar di banyak daerah di Indonesia ini cukup dapat memberikan gambaran terkait pelaksanaan kurban di daerah yang terdapat kasus Covid-19. Hampir di seluruh daerah di Indonesia telah melaporkan adanya kasus positif Covid-19 di daerahnya
(Covid19.go.id. 2020). Partisipan dalam kegiatan ini dikelompokkan berdasarkan keterlibatannya dalam pelaksanaan kegiatan kurban, yaitu masyarakat umum baik yang akan berkurban maupun tidak, petugas pemeriksa kesehatan hewan, dan panitia penyelenggara kegiatan kurban/Dewan Kemakmuran Masjid (DKM). Komposisi partisipan dalam evaluasi ini didapatkan sebesar 63\% masyarakat umum, 20\% panitia penyelenggara/DKM, dan $18 \%$ petugas pemeriksa kesehatan hewan. Dari seluruh partisipan ini sebanyak 90\% melaporkan bahwa akan melaksanakan kegiatan kurban meskipun dalam situasi pandemi dan meyakini bahwa pelaksanaan kurban di daerah mereka masingmasing akan berjalan dengan baik (Gambar 2).

Hasil evaluasi kesiapan diri menunjukkan bahwa tidak semua kelompok partisipan telah siap untuk melaksanakan kurban di tengah pandemi. Kelompok masyarakat umum secara signifikan memiliki poin yang lebih rendah dibandingkan dengan kelompok petugas pemeriksa hewan kurban dan panitia penyelenggara. Hasil analisis disajikan pada Tabel 1. Kelompok masyarakat umum memiliki rata-rata poin kesiapan diri $6,4 \pm 1,55$ yang berarti bahwa masih kurang siap. Petugas pemeriksa dan panitia penyelenggara mendapatkan poin $8,00 \pm 1,83$ dan $8,25 \pm 1,28$ yang berarti telah siap untuk pelaksanaan kurban di tengah pandemi.

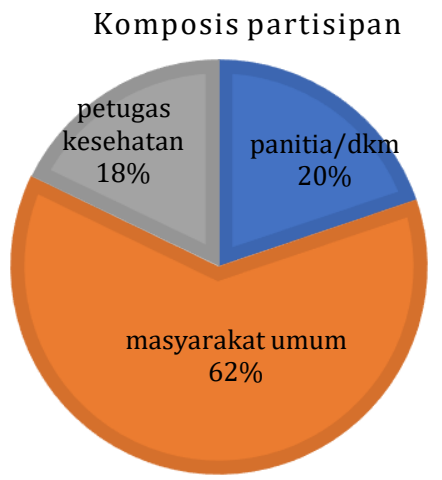

a

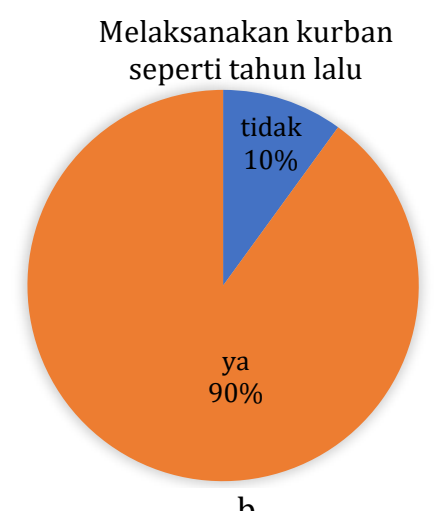

b

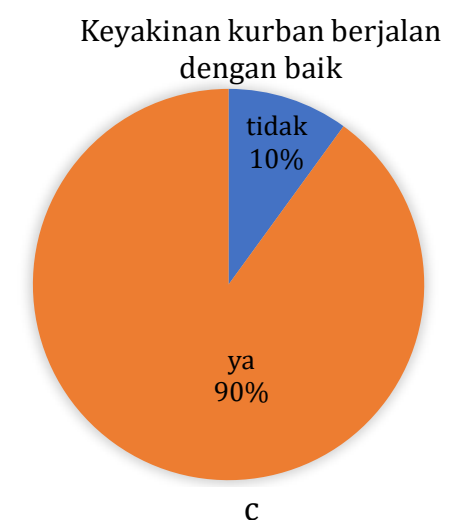

Gambar 2 a) Komposisi partisipan, b) Kepastiannya dalam melaksanakan kurban di tengah pandemi, dan c) Keyakinan partisipan bahwa kurban akan terlaksana dengan baik.

Tabel 1 Nilai evaluasi kesiapan diri partisipan dalam pelaksanaan kurban di masa pandemic

\begin{tabular}{lccc}
\hline \multirow{2}{*}{ Variabel } & \multicolumn{3}{c}{ Kelompok partisipan } \\
\cline { 2 - 4 } & Masyarakat umum & Petugas pemeriksa hewan & Panitia penyelenggara/DKM \\
Nilai kesiapan & $6,4 \pm 1,55^{\mathrm{b}}$ & $8,00 \pm 1,83^{\mathrm{a}}$ & $8,25 \pm 1,28^{\mathrm{a}}$ \\
Status & kurang siap & siap & siap
\end{tabular}

*Huruf superscript berbeda menunjukkan perbedaan signifikan $\mathrm{p}<0.05$

nilai $8-10=$ siap

nilai 6-8= kurang siap

nilai $<6=$ tidak siap 
Kesiapan dalam pelaksanaan kurban di tengah pandemi tentu berhubungan dengan gencarnya kegiatan sosialisasi yang ada. Ketiga kelompok partisipan memberikan jawaban yang berbeda seperti disajikan pada Gambar 3. Sebanyak 64\% dari kelompok masyarakat umum menyampaikan bahwa di lingkungan mereka tidak ada sosialisasi tentang protokol kurban di tengah pandemi. Pada kelompok petugas pemeriksa hewan kurban menyatakan ada sosialisasi sebesar $86 \%$ sedangkan pada kelompok panitia/ DKM sebnyak 50\%. Hal ini menunjukkan bahwa kegiatan sosialisasi yang ada telah dilaksanakan di tengah-tengah masyarakat namun masih perlu untuk ditingkatkan. Data ini juga sejalan dengan persentase keikutsertaan dari masing-masing kelompok partisipan tersebut dalam mengikuti kegiatan sosialisasi seperti disajikan pada Gambar 4.

Data menunjukkan bahwa hanya $24 \%$ dari masyarakat umum yang mengikuti kegiatan sosialisasi. Di sisi lain, petugas pemeriksa hewan kurban dan panitia sebanyak 86 dan $62 \%$ telah mengikuti kegiatan sosialisasi pelaksanaan kur- ban di tengah pandemi. Hasil dari mengikuti kegiatan sosialisasi memberikan pengetahuan dan kesiapan diri untuk melaksanakan kurban di tengah pandemi dengan baik. Selain itu, dengan mendapatkan pengetahuan melalui penyuluhan dapat meningkatkan kualitas penyelenggaraan kurban dengan meningkatnya aspek perhatian terhadap kesejahteraan hewan dan higiene sanitasi dalam penanganan hewan dan daging kurban (Winarso 2018).

Di sisi lain, pengetahuan masyarakat bahwa hewan kurban tidak menjadi sumber penularan dan pandemi Covid-19 sudah cukup baik, yaitu sebanyak 64\% kelompok masyarakat umum menyatakan tidak setuju saat diberi pertanyaan bahwa hewan kurban dapat menularkan Covid19. Sampai saat ini fakta menunjukkan bahwa hewan kurban bukan menjadi sumber penyebaran Covid-19 dan penyebab pandemi Covid-19 (Deptan 2020) sedangkan sumber penularan adalah dari manusia ke manusia (WHO 2020). Meski demikian masih ada sebanyak 16\% masyarakat menyatakan tidak tahu dan 20\% menyatakan setuju. Hasil berbeda diberikan oleh

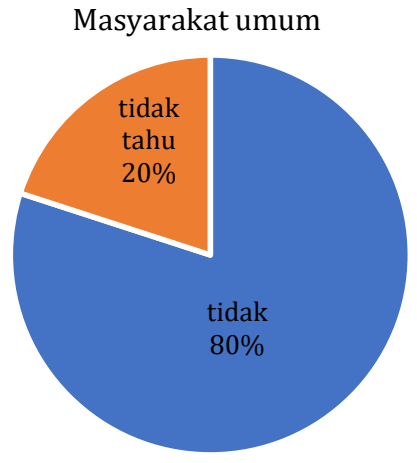

a

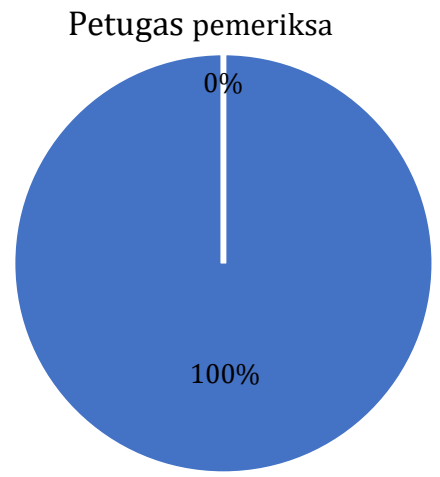

b

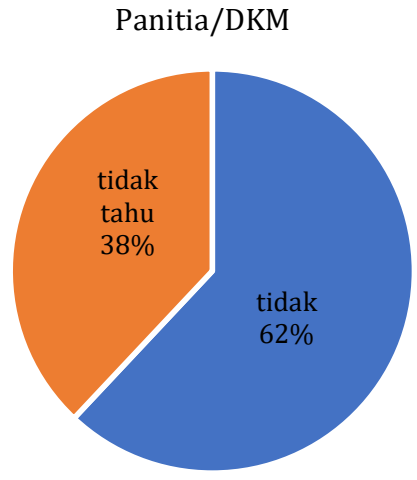

C

Gambar 3 Ada atau tidaknya sosialisasi di daerah masing-masing kepada: a) Masyarakat umum; b) Petugas pemeriksa; dan c) Panitia/DKM.

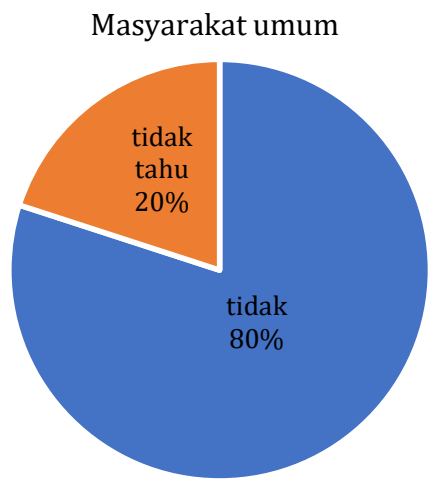

a

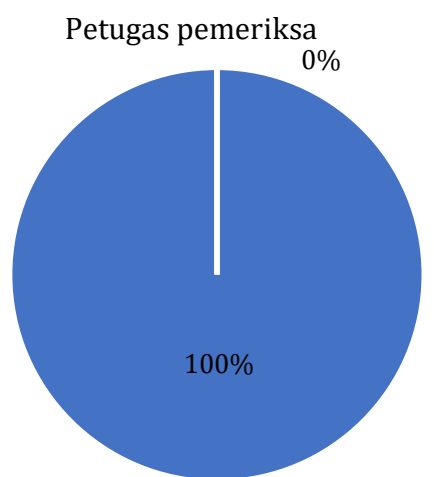

$\mathrm{b}$

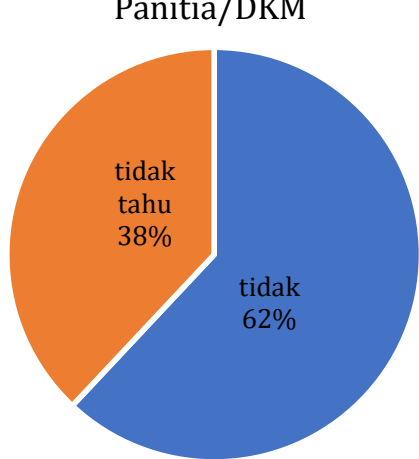

C

Gambar 4 Keikutsertaaan dalam kegiatan sosialisasi: a) Masyarakat umum; b) Petugas pemeriksa; dan c) Panitia/DKM. 
kelompok partisipan petugas pemeriksa kesehatan hewan dan panitia/DKM. Petugas pemeriksa hewan kurban $100 \%$ tahu bahwa hewan kurban bukan sumber penularan Covid-19. Kelompok partisipan panitia penyelenggara sebanyak 38\% tidak tahu sedangkan sebanyak $62 \%$ sudah mengetahuinya. Hasil tersebut disajikan pada Gambar 5.

Pengetahuan yang dimiliki oleh petugas dan panitia penyelenggara diikuti dengan kesiapan dan sosialisasi di daerah masing-masing yang dibuktikan sebanyak 72\% menyatakan bahwa di daerahnya sudah ada sosialisasi yang dilakukan dan persiapan untuk menerapkan protokol kesehatan. Persiapan dan sosialisasi ini paling tidak sudah dilakukan dalam seminggu sebelum pelaksanaan kurban. Rujukan pelaksanaan kurban di tengah pandemi Covid-19 merujuk pada Surat Edaran No. 0008/SE/PK.320/F/06/2020. Petugas pemeriksan hewan kurban dan panitia penyelenggara telah mengetahui adanya surat edaran ini sedangkan masyarakat umum masih sedikit yang mengetahuinya sebagaimana disajikan pada Gambar 6.
Sebanyak $71 \%$ petugas pemeriksa dan $75 \%$ panitia penyelenggara telah mengetahui adanya surat edaran mengenai tata cara pelaksanaan kurban ditengah pandemi. Di sisi lain, baru 28\% dari kelompok masyarakat umum yang mengetahui tentang surat edaran ini. Hal ini menunjukkan bahwa sosialisasi pada masyarakat masih perlu dilakukan di samping dari sosialisasi yang telah dilakukan oleh petugas pemeriksa hewan kurban maupun oleh panitia penyelenggara/DKM. Panitia penyelenggara atau DKM memiliki potensi besar untuk membantu sosialisasi terkait protokol pelaksanaan kurban di tengah pandemi. Sosialisasi ini dapat terjadi secara non formal melalui interaksi sehari-hari (Zihra 2018).

Pada hasil evaluasi kesiapan ini didapatkan informasi bahwa media yang digunakan untuk mencari informasi terkait pelaksanaan kurban di masa pandemi belum didominasi oleh media online. Hasil tersebut disajikan pada Gambar 7. Gambar 7 menunjukkan bahwa sosialisasi pelaksanaan kurban di tengah pandemi melalui webinar/seminar online telah banyak dilakukan

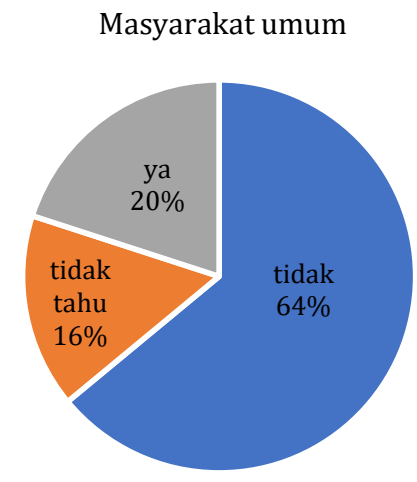

a

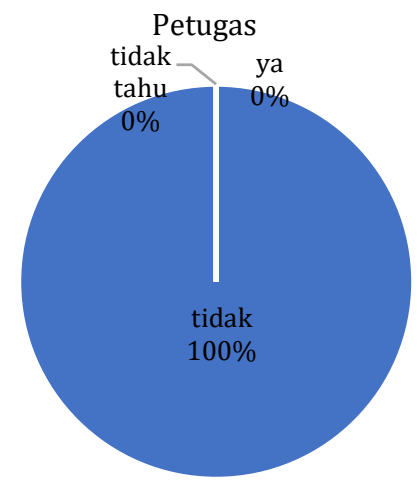

b

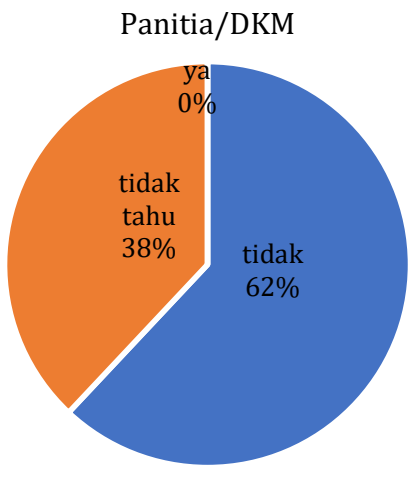

C

Gambar 5 Pengetahuan partisipan setuju atau tidak bahwa hewan kurban dapat menularkan Covid-19: a) Masyarakat umum; b) Petugas pemeriksa; dan c) Panitia/DKM.

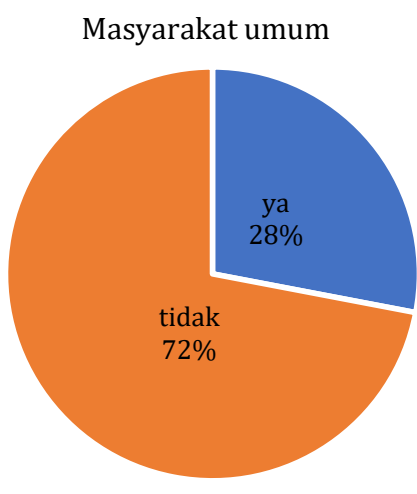

a

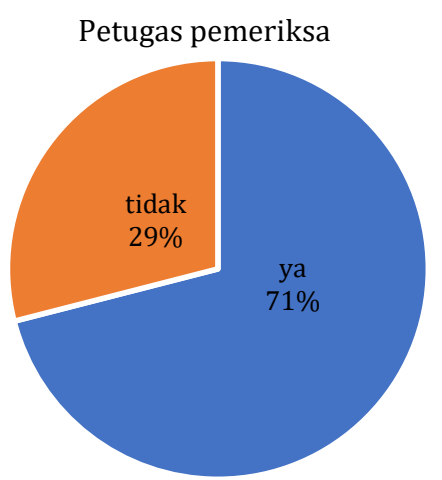

$\mathrm{b}$

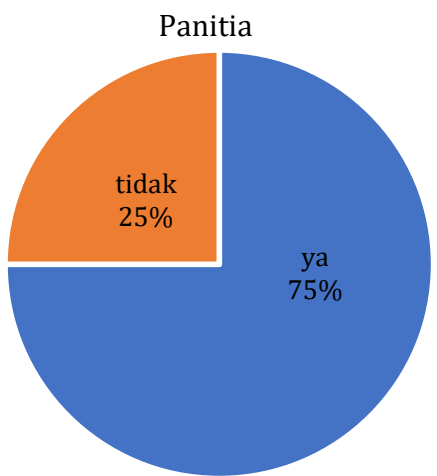

C

Gambar 6 Persentase pengetahuan partisipan terhadap Surat Edaran No. 0008/SE/PK.320/F /06/2020: a) Masyarakat umum; b) Petugas pemeriksa; dan c) Panitia/DKM. 


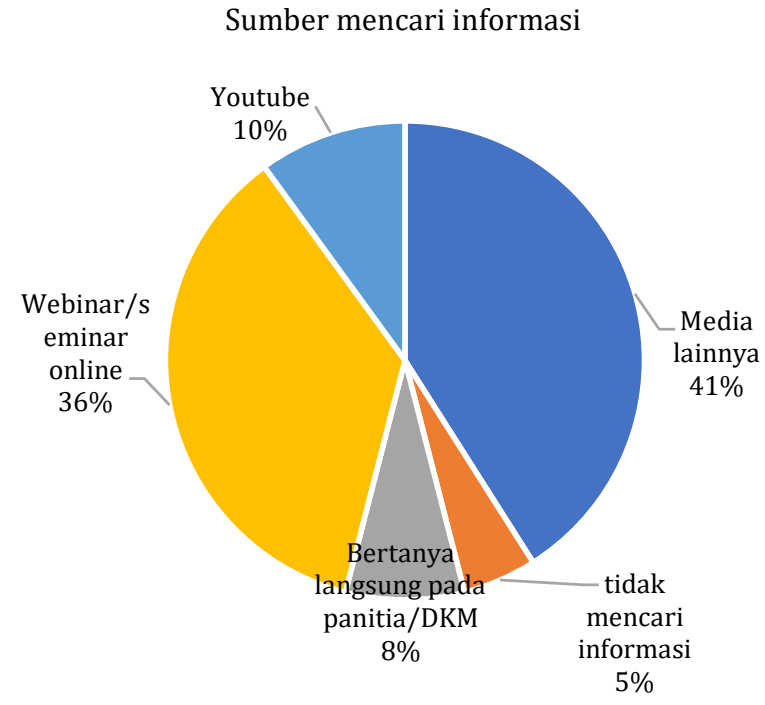

Gambar 7 Persentase media yang digunakan partisipan untuk mencari informasi mengenai protokol pelaksanaan kurban di masa pandemi.

dan membantu masyarakat untuk mendapatkan informasi yang tepat. Hal ini terlihat dari persentase masyarakat menggunakan media seminar online untuk mencari informasi sebesar 36\%. Di sisi lain, sebanyak 41\% masih menggunakan media lain untuk mencari informasi. Media lain ini dapat berupa diskusi atau bertanya langsung dengan teman, melihat poster, menonton televisi, atau media offline lainnya. Di situasi pandemi seperti saat ini, penggunaan media informasi secara elektronik sangat membantu untuk mempercepat sosialisasi kepada masyarakat (Komalasari 2020).

Pada akhir evaluasi kesiapan ini didapatkan fakta bahwa sebesar $87 \%$ partisipan masih membutuhkan informasi yang lebih terkait dengan pelaksanaan kurban di masa pandemi Covid-19. Hal ini menunjukkan bahwa baik petugas pemeriksa hewan kurban dan panitia penyelenggara/DKM yang diketahui telah memiliki kesiapan juga masih membutuhkan ketersediaan informasi di samping masyarakat umum yang lebih membutuhkan untuk mendapatkan informasi. Kegiatan sosialisasi dan penyajian informasi kepada masyarakat sangat diperlukan dalam upaya untuk meningkatkan pengetahuan terkait penerapan kebiasaan normal baru termasuk dalam pelaksanaan kurban (Satria et al. 2020). Untuk membantu masyarakat mendapatkan kemudahan informasi terkait pelaksanaan kurban di tengah pandemi, di akhir form evaluasi disediakan tautan menuju website resmi FKH IPB yang berisi materi rekaman seminar online tentang kurban di masa pandemi dan disediakan buku saku pelaksanaan kurban di masa pandemi yang dapat diakses secara gratis.

Salah satu contoh pelaksanaan kurban di tengah pandemi yang telah berjalan dengan baik sesuai anjuran pada SE No. 0008/SE/PK. 320/F/06/2020 adalah pelaksanaan kurban di Masjid An-Nashir di Perumahan Taman Darmaga Permai 2, Cihideung Udik, Ciampea, Bogor. Pelaksanaan kurban di Masjid An-Nashir ini memberikan contoh perbedaan kondisi antara pelaksanaan kurban pada tahun sebelumnya dibandingkan dengan pelaksanaan kurban di masa pandemi. Perubahan kondisi ini mencerminkan adanya perubahan persepsi di masyarakat antara pra dan pasca dilakukannya kegiatan pengabdian melalui edukasi oleh DKM. Sebelumnya, masyarakat secara bebas dapat untuk membantu dan bergabung pada hari pemotongan kurban sehingga kerumunan tidak dapat dihindari. Kondisi berbeda sudah dapat dilihat saat pelaksanaan kurban di tahun $1441 \mathrm{H}$ ini dimana hanya panitia yang terdaftar yang dapat masuk ke area pelaksanaan pemotongan hewan kurban sedangkan masyarakat yang berkurban dapat menyaksikan di tempat yang telah disediakan. Hal ini dapat tercapai karena DKM telah memberikan kontribusinya dalam mengedukasi masyarakat.

Dewan Kemakmuran Masjid (DKM) An-Nashir memberikan peran penting dalam fungsi edukasi kepada masyarakat sekitar sehingga pelaksanaan kurban dapat dilakukan dengan aman sesuai anjuran pemerintah. Pantia penyelenggara kurban telah dibentuk oleh DKM sebelum pelaksanaan kurban yang kemudian melakukan sosialisasi dan persiapan lokasi kurban. Lokasi kurban telah diatur sedemikian rupa sehingga terpisah antara area penampungan hewan, area kotor, dan area bersih. Fasilitas di lokasi pemotongan juga telah dilengkapi dengan peralatan yang memadai seperti penggantung karkas, terpal bersih, alas balok pemotong daging dan tulang, serta area pengemasan. Untuk pelaksanaan di masjid ini juga terdapat dokter hewan yang membantu pemeriksaan hewan kurban sebelum pemotongan, melakukan perubuhan hewan, dan pemeriksaan postmortem. Teknik perubuhan sapi yang dilaksanakan langsung dibantu oleh dokter hewan dengan menggunakan teknik burley yang mudah dipraktikkan dan tidak menyakiti hewan (Awaludin et al. 2017). Dokumentasi pelaksanaan kurban di Masjid An-Nashir disajikan pada Gambar 8.

Protokol kesehatan juga sangat diperhatikan. Pada area masuk lokasi pemotongan terdapat 


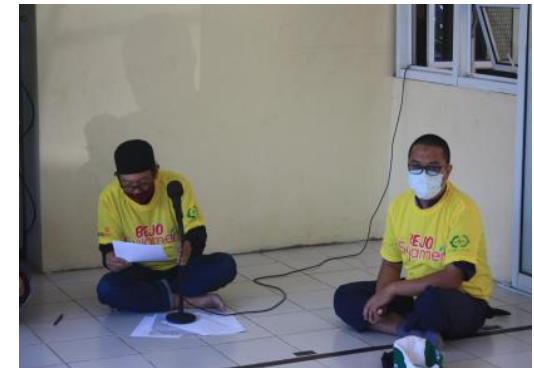

a

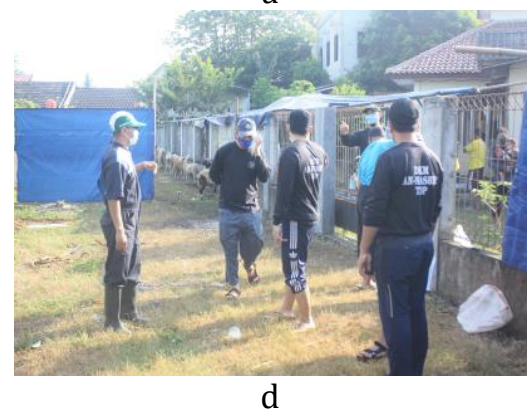

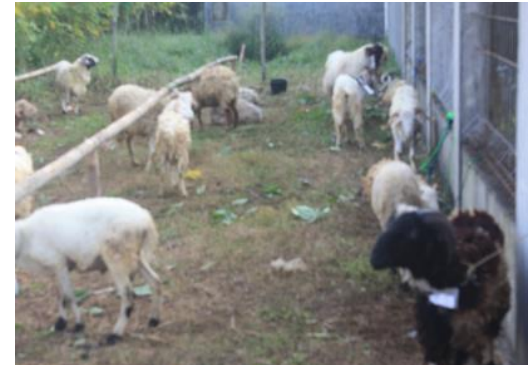

b

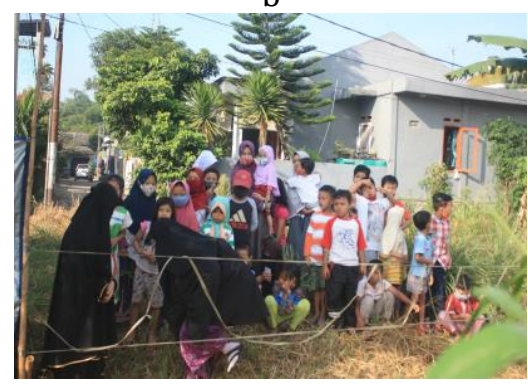

e

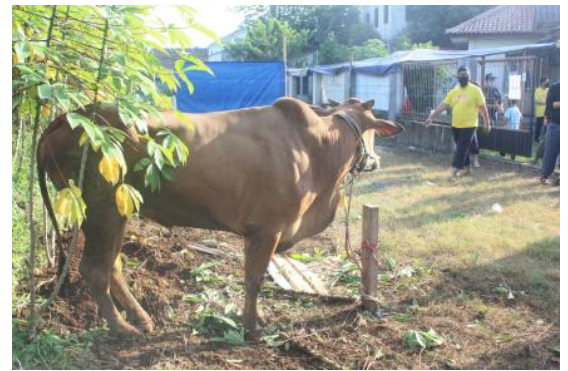

C

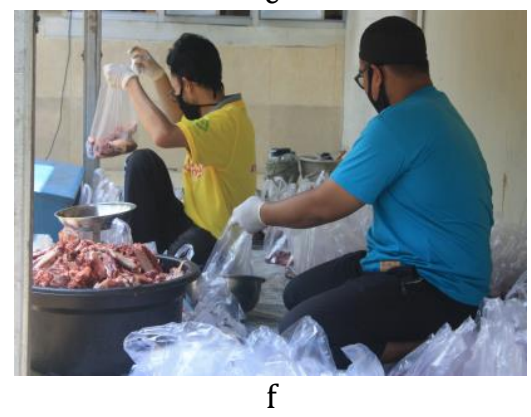

Gambar 8 Pelaksanaan kurban di Masjid An-Nashir: a) Koordinasi sebelum pemotongan hewan kurban, b dan c) Ternak ruminansia besar dan kecil dipisahkan tempat penampungannnya; d) Petugas pemotongan hewan kurban dibatasi jumlahnya dan selalu menerapkan protokol kesehatan; e) Warga yang ingin melihat proses pemotongan hewan kurban dibatasi aksesnya; dan f) Proses pengemasan paket kurban untuk siap diantarkan ke warga.

petugas yang akan memeriksa suhu dan menyediakan masker, sarung tangan, dan hand sanitizer. Area pemotongan juga dibatasi aksesnya dan dikhususkan bagi panitia dan orang yang akan berkurban untuk melihat penyembelihan hewan kurbannya. Setiap orang yang berada di lokasi pemotongan atau di sekitar masjid selalu diingatkan oleh koordinator lapang dari panitia penyelenggara untuk menerapkan protokol kesehatan seperti menjaga jarak minimal1 m, menggunakan masker, dan mencuci tangan sesering mungkin menggunakan sabun. Di akhir pelaksanaan kurban, paket kurban dibagikan oleh panitia penyelenggara dengan cara di antar ke rumah masing-masing penerima di mana datanya telah disiapkan beberapa hari sebelumnya. Hal ini sesuai dengan anjuran pada Surat Edaran No. 0008/SE/PK.320/F/06/2020 yang telah dikeluarkan oleh Dirjen Peternakan dan Kesehatan Hewan, Kementerian Pertanian.

\section{SIMPULAN}

Pelaksanaan kurban di masa pandemi merupakan salah satu bentuk penerapan kebiasaan normal baru di mana masyarakat masih membutuhkan pendampingan dan edukasi. Dewan Kemakmuran Masjid (DKM) memiliki peran strategis dalam membantu mengedukasi masyarakat dalam pelaksanaan kurban di tengah pandemi. Kegiatan pengabdian masyarakat ini dilakukan dengan mensinergikan peran FKH IPB dengan peran DKM dalam fungsi edukasi dan sosialisasi kepada masyarakat terkait pelaksanaan kurban yang baik dan aman di masa pandemi. Masyarakat menjadi lebih mudah mencari informasi yang jelas terkait dengan pelaksanaan kurban yang aman dan mendapat penjelasan yang akurat terkait sumber penularan Covid-19. Saran yang dapat diberikan untuk pelaksanaan kegiatan pengabdian masyarakat ini adalah dibentuknya forum antar DKM dalam cakupan satu wilayah desa. Forum DKM tersebut dapat menjadi sarana saling berbagi ilmu dan praktik dalam pelaksanaan kurban di tengah pandemi. Melihat bahwa DKM terbukti berperan penting dalam fungsi edukasi kegiatan ini maka forum DKM dapat memberikan cakupan edukasi yang lebih luas dan efektif untuk masyarakat.

\section{UCAPAN TERIMA KASIH}

Terima kasih kepada Fakultas Kedokteran Hewan IPB yang telah menyediakan hosting online untuk materi edukasi, kepada panitia hewan kurban tahun 2019 yang telah menyediakan materi untuk penyusunan buku saku kurban, dan Masjid An-Nashir Perumahan Taman Darmaga Permai 2 Desa Cihideung Udik, Ciampea, Bogor, Jawa Barat. 


\section{DAFTAR PUSTAKA}

Atalan A. 2020. Is the Lockdown Important to Prevent the COVID-19 Pandemic? Effects on Psychology , Environment and EconomyPerspective. Annals of Medicine and Surgery. 56: 38-42. https://doi.org/10.1016/j.amsu. 2020.06.010

Awaludin A, Nugraheni YR, Nusantoro S. 2017. Teknik Handling dan Penyembelihan Hewan Qurban. Jurnal Pengabdian Masyarakat Peternakan 2 (2): 84-97. https://doi.org/10. 35726/jpmp.v2i2.209

[BPS] Badan Pusat Statistik. 2020. Populasi Ternak Menurut Provinsi dan Jenis Ternak (ribu ekor), 2018, 2019. Statistik Indonesia 2020. Jakarta (ID): Badan Pusat Statistik. Hal. 310-311.

covid19.go.id. 2020. Peta Sebaran. [Internet]. [Diakses pada: 26 Agustus 2020]. Tersedia pada: https://covid19.go.id/peta-sebaran

[Deptan] Departemen Pertanian. 2020. [Internet]. [Diakses pada: 24 Agustus 2020. Tersedia pada: https://www.pertanian.go.id/home/?show= news\&act $=$ view\&id=3909.

Fitriyana N. 2020. God Spot dan Tatanan New Normal di Tengah Pandemi Covid-19. Jurnal Ilmu Agama. 21(1): 1-24. https://doi.org/ 10.47902/mauidhoh.v1i2.71

Habibi A. 2020. Normal Baru Pasca Covid-19. 'Adalah: Buletin Hukum Dan Keadilan. 4 (1): 197-204.

Kementerian Kesehatan. 2020. Keputusan Menteri Kesehatan Republik Indonesia Nomor HK.01.07/MENKES/382/2020 Tentang Protokol Kesehatan Bagi Masyarakat di Tempat dan Fasilitas Umum dalam Rangka Pencegahan dan Pengendalian Corona Virus Disease 2019 (COVID-19). Jakarta (ID): Kementerian Kesehatan RI.

Komalasari R. 2020. Manfaat Teknologi Informasi dan Komunikasi di Masa Pandemi Covid-19. Jurnal Tematik. 7(1): 38-50. https://doi.org/ 10.38204/tematik.v7i1.369

Muhyiddin, Wardhana D. 2020. Covid-19 Outbreak and Development Planning in Indonesia. The Indonesian Journal of
Development Planning. 4(1): iv-vi (Editorial Note). https://doi.org/10.1177/ 000944559803400206.

[MUI] Majelis Ulama Indonesia. 2020. Fatwa MUI No 36 Tentang Shalat Idul Adha Dan Penyembelihan Hewan Kurban Saat Wabah Covid-19. [Internet]. [Diakses pada: 26 Agustus 2020]. Tersedia pada: https://mui.or.id/produk/fatwa/28586/fatw a-no-36-mui-tentang-shalat-idul-adha-danpenyembelihan-hewan-kurban-saat-wabahcovid-19/

Mulyana A. 2016. Qurban: Wujud Kedekatan Seorang Hamba Dengan Tuhannya. Jurnal Pendidikan Agama Islam. 14(1): 109-16.

Saputra A, Rospita M, Shofiah V. 2019. Qalbu Dalam Kajian Psikologi Islam. Jurnal Ilmiah Keislaman. 18(1): 37-51. https://doi.org/ 10.24014/af.v18i1.7154

Satria BA, Hasanah NH, Rudiansyah. 2020. Penyuluhan Adaptasi Tatanan Kebiasaan Baru Desa Tangguh Covid-19. ANOA. 1(3): 107-22.

[WHO] World Health Organization. 2020. Transmission of SARS-CoV-2: implications for infection prevention precautions. [Internet]. [Diakses pada: 24 Agustus 2020].Tersedia pada:

https://www.who.int/publications/i/item/m odes-of-transmission-of-virus-causing-covid19-implications-for-ipc-precautionrecommendations

Winarso A. 2018. Promosi Kesejahteraan Hewan dan Higiene Sanitasi dalam Penyembelihan Hewan Kurban di Kota Kupang. ARSHI Veterinary Letters. 2(3): 57-58. https://doi. org/10.29244/avl.2.3.57-58

Wu YC, Chen CS, Chan YJ. 2020. The Outbreak of COVID-19: An Overview. Journal of the Chinese Medical Association. 83(3): 217-20. https:// doi.org/10.1097/JCMA.0000000000000270

Yuliana. 2020. Wellness and Healthy Magazine. Wellness And Healthy Magazine. 2: 187-92. https://doi.org/10.30604/well.95212020

Zihra AM. 2018. Pemberdayaan Masyarakat Berbasis Masjid. Lembaran Masyarakat: Jurnal Pengembangan Masyarakat Islam. 4(1): 5774. 